\title{
Rock Beats the Wall? On Commemorative Practices in Post-Soviet Russia
}

\author{
Nina Cingerová, Irina Dulebová \\ Comenius University
}

\begin{abstract}
This paper focuses on the case analysis of the memorial to the victims of state terror - the Wall of Grief (Stena skorbi) - which was unveiled on the eve of the 100th anniversary of the November 7, 1917, coup d'état. Using this example, we have attempted to elaborate a structure for a more complex analysis of the memory of past regimes' manifestation and to create a methodological base for their comparison. We have based our research on the discourse theory by the so-called Essex School, the social semiotics by Kress, and the procedures of the critical discourse analysis. The procedure that we have considered relevant consists of the following: (a) description of the social context in which the memorial was manifested as a piece of evidence; (b) semiotic analysis of the memorial artifact; (c) analysis of verbal practices, as well as written and spoken texts that "explained" the memorial; and (d) analysis of nonverbal practices, namely, rituals. On the basis of our case study, we have come to the conclusion that when carrying out a semiotic analysis and the analysis of verbal and nonverbal practices in the case of the Russian public discourse, it is especially relevant to pay attention not only to widening vs. narrowing of the chronological framework, generalization vs. concretization, and specification of the traumatic experience but also to the question of framing of the memorial. In regard to the semiotic analysis, the extent of indexicality is considered to be very important in the sense of the bodily connection with an element of the commemorated event that bestows "truthfulness" and authenticity on the memorial. We assume that particularly present-day Russia, where explicit attempts to reinterpret the history of the authoritarian communist state and attempts to instrumentalize the totalitarian period according to the vector of the current political direction may be seen, is a relevant object of this kind of research.
\end{abstract}

\section{Keywords}

Memorial culture; Russia; Stalinism; discourse analysis; semiotic analysis

\section{Introduction}

Memorials and monuments represent the manifestation of narratives about events and people that are/were so much important to a certain imagined community that its members put a public spotlight on them. These objectified

\footnotetext{
* Nina Cingerová, Comenius University in Bratislava, Faculty of Arts, Gondova 2, 81102 Bratislava, Slovakia, nina.cingerova@uniba.sk; Irina Dulebová (corresponding author), Comenius University in Bratislava, Faculty of Arts, Gondova 2, 81102 Bratislava, Slovakia, irina.dulebova@uniba.sk.
} 
narratives about heroes; cultural, statesmanlike, moral, and other standards; victories; and victims who have been claimed are becoming an integral part of communities' memorial culture as a collective "embracement of the past (Aneignung der Vergangenheit)" (Assmann, A. 2013, 31-32). From this viewpoint, they - to a large extent - contribute to the demarcation of a community's borders, i.e., they shape the discourse about its identity; they "concretize" it (Assmann, J. 1988, 13).

A monument represents a very specific type of message. It is usually articulated through a code that does not have the same amount of effability as the verbal language (Eco 1976, 172), and its meaning is anchored additionally. It is outlined either by being incorporated into an existing "text" of landscape, i.e., by the spatial context (location, relocation, and replacement) or by various verbal (speeches, media texts) and nonverbal actions (various social rituals, monument modifications). In the interaction with the body of a monument, these practices construct the fundamental architecture of relevant events, respected values, "heroes", and "enemies".

These evidences of the past are always articulated with regard to the "needs" and coordinates of the current space-time reference. They are acquired within certain discourses in accordance with the notional rules of formation (Foucault 2002, 42, 44-47), determining what may be said and how it may be said. And vice versa: updates of the "memory", which are presented in public and shared on the collective level, have the potential to continue to shape related discourses.

After the breakup of the Eastern Bloc, experience with past regimes has become that sort of important event for the former socialist countries. It has been transformed into numerous material representations, including memorials/monuments. This paper pays attention to one of their subgroups - monuments to the victims of state terror, focusing on the context of present-day Russia. We suppose that especially present-day Russia, where explicit attempts to reinterpret the history of the authoritarian communist state and attempts to instrumentalize the totalitarian period according to the vector of the current political direction may be seen, is a relevant object of this kind of research.

We perceive our article as a contribution to historiographical, sociological, anthropological, cultural, and political science research in the fields of politics of memory, memory studies, as well as transitional justice and trauma studies. Regarding the current research on the debated topic, the 
works of Koposov (2011), with reference to Russian scholars, ' and Bogumił, with reference to non-Russian scholars, need to be mentioned. ${ }^{2}$ In our study, however, we mainly follow the ideas of cultural historian Etkind (2013) and his thesis on "hard memory" and "soft memory". Etkind says that memory can be thought of as a computer - it has its software and hardware components: soft memory consists primarily of texts, while hard memory consists primarily of monuments (Etkind 2013, 177). Soft and hard memories need each other. "Monuments without inscriptions are mute, while texts without monuments are ephemeral. The monumental hardware of cultural memory does not function unless it interacts with its discursive software", writes Etkind (2013, 177). In this sense, from linguistic positions, instead of finding political causalities, we focus primarily on (widely understood) texts of various types, as well as the interaction of verbal and nonverbal practices. Our contribution is to provide sufficient grounds for the analysis of monuments, in addition to presenting the methodological basis and the model of analysis, which would enable more complex comparative research. We want to introduce this subject on the basis of the analysis of the so-called "Wall of Grief" (Stena skorbi), which was unveiled in Moscow on the 100th anniversary of the November 7, 1917, coup d'état.

The article is structured as follows. The article first presents the basic concepts and principles of the discourse theory by Laclau and Mouffe, which was an important foundation for our reflection on the analysis and nature of the interaction of verbal and nonverbal practices. Based on the discursive nature of verbal and nonverbal practices and their potential to transform or to stabilize the identity of elements or entire narratives/discourses, we set out the basic steps in their analysis in the next section. We subsequently present the model of analysis based on the example of the unveiling ceremony of the Moscow memorial "The Wall of Grief"; we are interested not only in the narratives produced by Russian government officials but also in the competitive narratives produced.

\section{Memorials as Crossroads of Verbal and Nonverbal Practices}

Our idea of the analysis was based on the discourse theory by Laclau and Mouffe. They understand discourse as "structured totality resulting from the articulatory practice" (Laclau and Mouffe 2001, 105). Articulatory

\footnotetext{
1 A detailed overview of the research of Russian scientists in the field of politics of memory is offered in the review article: Rostovtzev, E. A. - Sosnytskiy, D. A. Napravlenyya issledovaniy istoricheskoy pamyati in Rossia. In: Vestnik Sankt-Peterburgskogo Universiteta, Ser. 2, Off. 2, 2014, pp. 106-126.

2 Cf. especially the review work: Bogumił, Z. Pamięć Gułagu. Kraków: Universitas, 2012.
} 
practice (articulation) is composed of verbal and nonverbal practices that determine the identity of elements within a particular system (Laclau and Mouffe 2001, 105). However, those are always fixed only temporarily and partially, in some kind of "reservoir" (Jørgensen and Phillips 2002, 27). All the possible, moving, floating identities of signs, called elements by Laclau and Mouffe $(2001,105)$, are present in what the authors call the field of discursivity (Laclau and Mouffe 2001, 111). In the "battle for meanings", however, only some of them are articulated. These relative positions that are articulated in the discourse, and thus temporarily fixed, are called moments by Laclau and Mouffe (2001, 105-106). Others remain in the field of discursivity, producing the surplus of meaning (Laclau and Mouffe 2001, 111) and thus becoming a precondition for other possible fixation of meanings. If we extrapolate these propositions on the subject of our research, we may state that in the field of discursivity, there is all the accessible information about the persons or events whose truth value does not depend on personal opinions, preconceptions, and preferences (compare Searle 1995, 27), nor on their potential assessments. Depending on the current "needs", some of them are articulated and shaped as the relevant ones. Particular articulations may be anchored by various discourse dominants, the so-called nodal points (Laclau and Mouffe 2001, 112 ), or may be antagonistically opposed to each other, and they may serve in a position of the mutual constitutive outside (Laclau 1990, 136-137, 183; Torfing 1999, 124-125; compare also Staten 1984, 24).

These various articulations may be manifested on various institutional levels and in various codes. While analyzing the memorial as a statement that shapes the importance of a particular historical event or figure, we consider not only the nonverbal communication but also the verbal communication, which additionally specifies the importance of the memorial object (Barthes 1977, 38-41). Not only the memorial itself but also the unveiling of the memorial or any other situation when the memorial is commented on, assessed, or referred to may be seen as an especially important object from the viewpoint of the discourse analysis of a particular event or figure. These may be categorized as the discourse events (diskursive Ereignisse), because they are often high-profile events from the viewpoint of politics and media and, from this position, they determine the quality and direction of constructing the entity and the shaping of other related entities as well (Jäger and Jäger 2007, 27). That is why we mainly consider the discourse events when structuring a more extensive analysis of a particular discourse chain (Diskursstrang), i.e., discourse fragments (Diskursfragmente) connected with one topic (Jäger, Jäger 2007, 25) (e.g., discourse about Stalin); they represent the preferred subject of the detailed analysis. 


\section{Analysis Procedure}

In the context of the above-mentioned points, a relevant analysis method/ procedure shall consist of the following: (a) description of the social context in which the memorial was manifested as an evidence; (b) semiotic analysis of memorial artifacts - monuments, memorials, or memorial places that represent objectified manifestations of certain narratives and stories; (c) analysis of verbal practices, as well as written and spoken texts that "explain" the memorials; (d) analysis of nonverbal practices, namely, rituals.

\section{Semiotic Analysis of Memorial Artifacts}

We approach the semiotic analysis of a memorial from the viewpoint of social semiotics in the interpretation of van Leeuwen and Kress (2010). It puts emphasis on the "production" and use of signs, as well as analysis of semiotic options and "choices" (Kress 2010, 54-78). For us, it was analytically useful primarily because it treats signs as something that are intentionally used and "woven" into wider social practice. We ask ourselves the following questions: How was a memorial incorporated into the landscape and what "contextual pressure" on its interpretation may be assumed when speaking of its most probable reading? What resources for its representation (e.g., color, material, shape, and font type) have been used? What is the potential of the resources (and signs) that have been used? What is the relationship between resources and particular signs? What meaning has been created? How has it been created? (cf. Kress 2010, 57-58).

When identifying relevant resources and signs, it is appropriate to use the so-called commutation test, which was originally worked out within the Prague (in experiments with changing the sound structure of words) and the Copenhagen School of Linguistics (Hjelmslev 1969, 73-75). The key question we ask ourselves when taking this test is whether a change on the level of a signifier would lead to a change on the level of the signified. In the practice of the analysis, it means choosing some signifier and considering other "choices" and options (Chandler 2007, 88-93).

In the case of the used signs and their potential, it seems fruitful to ask a question concerning the sign type. In this regard, Peirce's categorization may be seen as a relevant one. In connection with the degree of motivation of particular signs and their relation to the entity they represent, he differentiates between icons (resemblance), indices (causal relationship), and symbols (arbitrariness) (Peirce 1972, 17-45). What may be considered relevant is also the rationale behind metamorphoses of particular signs, such as the 
symbolization of icons and symbolization of indices, which enable transparent and effective communication (Keller 1995, 165-174).

For example, the specific character of the memorial plaque in the form of a reconstructed authentic writing "ВЕРБА", ${ }^{3}$ which was unveiled in 2013 in the Štúrova Street in Bratislava, may be aptly described in semiotic categories. The sender of the authentic message is not the commemorating society (Slovak society), but members of the commemorated group (Red Army). In the process of memorialization, the authentic message they left on the wall has become a signifier of the more complex signified, which comprises such meanings as "liberation of Bratislava" and "commemoration of Bratislava's liberators". It, thus, combines not only characteristics of the index sign, referring to and being "bodily" linked to the particular events of 1945, but also the characteristics of the symbol, stimulating the interpretation based on the rule: the one who did X can be considered Y (Keller 1995, 166). In regard to the interpretation of the memorial, it is also important that in comparison with other memorials, pars pro toto representing the liberation events, the "VERBA" memorial is not so prone to further "undesirable" symbolization. For example, a tank as a memorial is a much more ambivalent sign. In the present-day industrial society, this "body" belongs to frequently used collective symbols (within the terminology of Link and Jäger; compare Jäger and Jäger 2007, 39-61). It is polysemous, syntagmatically expansive (it opens the way to the field of symbols that belongs to the same semantic field: wars, soldiers, shooting, and so on), and visually easily depictable (it may be photographed, drawn, and painted). Due to its "iconogenic character", it is able to create associations and references to other events, other tanks, as well as not only liberation, but also occupation.

Finally, there is also a phenomenon of production of signs. In the case of memorials, a phenomenon of ostension, communication by showing, "the language of things" (Osolsober 2002, 16), comes to the fore rather clearly. By means of attaching a pane of glass on the wall over the writing, i.e., by means of presentation of a ready-made object and its later ritualized unveiling, comprising verbal and nonverbal acts, the above-mentioned writing has become a memorial. At the same time, this act highlights not only the concrete object (viz., the writing) but the whole discourse as well (compare Eco 1976, 225). Owing to this fact, it is, in its essence, an interesting artifact of the memorial culture, mainly in the sense that it considerably differs from other

\footnotetext{
3 The "VERBA" writing was left by Soviet army engineers who were clearing Bratislava of mines in April 1945. It was a code word that the members of the same discourse community could easily interpret as: the building was inspected and cleared of mines. 
(triumphal and monumental) memorials with which it forms one paradigm "memorials to the liberators". It is authentic and "speaks for itself". It is exactly the authenticity that may come to the fore as a counterweight to the pathos, institutionalization, and clichéd nature of the memorial culture (Assmann, A. 2013, 76-77).

\section{Analysis of Verbal and Nonverbal Practices}

When analyzing the verbal practices, we focus on some discourse fragments, such as the speeches given next to memorials or the media texts that "describe" and comment on them. We regard Reisigl and Wodak's (2001) method of analyzing discourse fragments as a clearly structured one. The authors differentiate three basic spheres that an analyst should pay attention to: (a) identification of the specific content, articulated topics, and subtopics, as well as their structuring; (b) identification of discourse strategies (including argumentation strategies); and (c) identification of language means and specific linguistic manifestations (Reisigl and Wodak 2001, 44). From the heuristic point of view, it is possible to focus on the following questions: how are the persons, objects, phenomena/events, processes, and actions named? What characteristics, qualities, and features are attributed to the persons, objects, phenomena/events, and processes? What arguments are used within the given discourse? From what perspectives are these namings, attributes, and arguments expressed? (Reisigl and Wodak 2001, 44) Deriving the basic grammar of a story may be taken into consideration as well. In the example of memorials devoted to the victims, this process may mean to concentrate on assigning a particular "role" to somebody: Who is the culprit/perpetrator/ enemy? What was his/her motivation? Who are the victims? Of what nature is the grief, and what really happened? (Alexander 2015, 109-110).

Nonverbal practices represent the rituals that both contribute to the sedimentation of narratives about particular events/persons/collective subjects and facilitate their inclusion in the events/persons constituting a part of a community's collective memory and forming their desired interpretation and framing. ${ }^{4}$ Their absence in the position of the zero sign is important as well. However, we must point out that within the analysis, it is often problematic to study verbal and nonverbal practices separately.

4 The term frame is understood according to Fillmore as a "system of concepts related in such a way that to understand any one of them you have to understand the whole structure in which it fits; when one of the things in such a structure is introduced into a text, or into a conversation, all of the others are automatically made available". Compare Fillmore 1982, 111. 


\section{Wall of Grief}

\section{Social Context}

In the context of the presented research, the current (one of many in Russian history, ranging from absolute glorification to total demonization) resemantization of the surname Stalin, which speaks volumes about the direction of present-day Russian society, is very important. In February 2017, a survey by the agency Yuri Levada Analytical Center stated that the positive assessment of this historical figure by the Russian respondents (46\%) was at its highest in the past 16 years. In the summer of 2017, the rankings of the most popular historical figures (according to the Levada-Center) was topped by Stalin (38\% of respondents), who was ahead of Putin (34\% of respondents) and Lenin (32\% of respondents) (Levada 2017).

Apart from the general framework, it must be mentioned that the memorial was unveiled on the eve of the 100th anniversary of the 1917 Russian Revolution, construction of which had been discoursively suppressed. The central argument of the interpretation, in the context of color revolutions and protest moods in Russia, was that the revolution had been bad because each coup d'état was bad and because reconciling and unifying the society were important. As the cultural historian Ilya Kalinin wrote in this regard:

"The challenge incited by the anniversary of the revolution lies in the necessity to uncover the revolutionary meaning of the event itself in a historical narrative denying the revolution as such."(Kalinin 2017)

Another relevant fact in regard to the social context was that the unveiling of the memorial took place on the eve of the presidential elections. It was thus perceived also as the start of the election campaign of the current President Vladimir Putin.

Last, but not the least, in the context of constructing the remembrance, we must point out that the social and political events that went hand in hand with condemnation of Stalin's repressions seemed rather paradoxical. The unveiling, as a matter of fact, took place at the time when politically motivated prosecutions and the freedom of speech restrictions stirred up debate in Russia. The reason was the prosecution for posting comments on social networks. As one of the first cases, we may name the case of Rafis Kashapov, the head of the Tatar Public Center. He was sentenced in 2015 for posting six articles, such as "Crimea and Ukraine will be free from occupants!", "Yesterday Hitler and Gdansk, today Putin and Donetsk", "We will protect Ukraine and the

5 "Vyzov, provotsiruyemyy yubileyem revolyutsii, zaklyuchayetsya v neobkhodimosti rastvorit' revolyutsionnyy smysl samogo sobytiya $v$ istoricheskom narrative, otritsayushchem revolyutsiyu kak takovuyu." 
whole Turkish world", and "Wherever Russia is, there are tears and death", on his own page on the social network "VKontakte", under his own and his brother's names. The court considered his actions to be "inciting hatred". The verdict was then criticized by the important human rights organization "SOVA Centre for Information and Analysis" (Sova 2015) also. Referring to the human rights organization "Agora", the news site Gazeta.ru, which aimed to map the prosecutions for reposts and comments on social networks, stated that, in 2017, the courts sentenced 48 users for posting on social networks and 411 users were involved in a criminal proceeding (Bevza 2018). It was not just a debate on restricting the freedom of speech. The nongovernmental organization "Memorial", aimed at revealing the crimes of Stalinism, has been subjected to social and, last but not the least, legal stigmatization ("foreign agent") (Racheva 2016). Moreover, the current officials of the interior and defense departments often downplay these issues (compare Bortnikov et al. 2017). It may be, thus, stated that in the Russian society, contradictory signals are being sent "from above", creating a polyphonic context of the given event.

\section{Semiotic Analysis of the Memorial}

The Sakharov Center (Sakharovskiy tsentr), a nongovernmental organization whose objective is "to develop a historical consciousness of Soviet totalitarianism and the resistance to oppression", lists 714 memorials and memorial plaques devoted to the victims of political repressions that are located in the Russian Federation (Pamyatniki 2019). ${ }^{6}$ Most of them are located in the Komi Republic (68), Perm Krai (64), and Moscow (44).

The Wall of Grief was unveiled as one of the latest memorials in Moscow. It was built according to the design of the sculptor Georgy Frangulyan. It is a bronze bas-relief, a 6-m-high and 35-m-long columbarium, on which there are faceless human figures. In some places, the wall may be crossed through human silhouettes. There is a word "Remember" in 22 languages inscribed sideways on the wall. The space in front of the wall is paved with stones that come from the places where the victims of political repressions were serving their sentence. Streams of water flow down the stones/boulders arranged around the square.

With respect to the location that "speaks for itself", it must be mentioned that the memorial is located in an unattractive place from the point of view of tourists (at the intersection of Prospekt Akademika Sakharova and Sadovoye Kol'tso in the wider center of Moscow). It is not considered to be

6 The list also features the memorial plaques commemorating famous people without being explicitly stated that they had become the victims of repressions. 
a pedestrian area for the locals. It is located next to a busy multilane road in a residential quarter away from the historical sights. Moreover, there is no underground station nearby and that is very important from the viewpoint of its prominence.

The memorial will be therefore taken into consideration as a message, a component of the semiotic act that uses several sources for its representation (material, shape, color, font type, sound, and so on). In the case of communication via this artifact, we have something to do with a situation when the sender of a message proposes correlations and the recipients are expected to reconstruct the code in which the message was executed (Eco 1976, 188-189). And the memorial is extraordinary exactly in this aspect. It abets the reconstruction via direct common human experience that should evoke the content not easily described in the verbal code. It is "interactive"; it becomes a functional object, a tool for experiencing a sum of emotions. We may thus hear "crying" (water streaming down the stones) and experience "violence" (rough, unhewn texture, and used material), and the recipient has an option of directly becoming one among the mass of people depicted on the bas-relief by passing through the silhouette opening. ${ }^{7}$ In this respect, the expressive function comes to the fore, suppressing the cognitive function (in Roman Jakobson's terms), especially when comparing it with those "classic" memorials devoted to victims, which consist of a plaque/obelisk or other type of surface with the victims' names or portraits inscribed on it (compare Pamyatniki 2019). The Wall of Grief is special because its attention is primarily aimed at thematizing and evoking the mass character and the large extent of violence, heaviness, grief, and inclusion, i.e., the entities that are not easily verbalized and visualized or, more precisely, which may be represented by various signifiers or chains of signifiers.

Of course, the memorial thematizes the victims as well, but from a very specific position. As its name itself indicates, it is a memorial - columbarium; we do not find any elements referring to concrete individuals there, but they come to the fore as the (faceless) mass of people, as the collective victim. In this sense, as a message, it significantly differs from the numerous commemorative practices within the given discourse, whose objective is to concretize the victims, to say their names, to give a vivid picture of their fates, and to thematize the emptiness that they had left behind. In the context of commemorating repressions, we may mention, for instance, the Garden of

7 In this aspect (creating an iconic experience, iconic in the sense of simulating analogous perceptive conditions; compare Eco 1976, 195), it resembles The Memorial to the Murdered Jews of Europe in Berlin, designed by Eisenman. 
Memory, which was opened at the Butovo firing range in 2017 (Yemelyanenko 2017), the place where $>20,000$ people were executed in 1937; the so-called "Returning the Names" event - the reading of victims' names next to the Solovetsky Stone memorial, which has been held annually since 2007 on the Day of Remembrance of the Victims of Political Repressions (Giniatulina 2010); the Last Address initiative, which installs a small commemorative plaque on the houses known as the last residential addresses of the victims of repressions (Adres); the People Against Stalin project, under which people attached to their clothes sheets of paper with the names of victims and also the publication of all the names of victims, which is considered the objective of the Memorial's organization (Zhertvy). Just for the record, we must mention that the concretization may be aimed not only at victims but on perpetrators as well. Another good example, although from a different context, is the House of Terror (fascist and communist) in Budapest, where visitors can see also the faces of "executioners" (the wall with photographs of the members of the Hungarian state police).

In general, it may be stated that the Wall of Grief operates more likely within the categories of dealing with the grief as the result of repressions than within the concretization of victims and the guilt of perpetrators.

One of the important elements of the memorial is a path leading toward the columbarium and paved with stones sourced from the labor camps where the victims of repressions had been placed. In this case, it is a complex sign combining the characteristics of an icon, an index, and a symbol. It is a "real" object, not intentionally made, essentially, pars pro toto, connected to the entities it represents (labor camps). A recipient of the message (memorial), in a similar way as the victims, passes through the "camps" in order to reach the center of the memorial, the columbarium, and to become one of "them". And finally, there is a symbolic potential of this element (a journey as the final journey and death), which is so usual that it is reflected in a set phrase posledniy put' (final journey; in the Russian language, put' means "pathway" as well as "journey").

We assume that from the viewpoint of analyzing memorials, an extremely important factor is the indexicality, in the sense of fundamental connection of the body of a sign to the commemorated entity. It improves the memorials' authenticity, which in turn tend to make a real, true impression, deriving this potential from contact with the commemorated entity. That is why the Solovetsky Stone memorial makes such a strong impression on the recipient. The granite boulder, which was shipped in 1990 from the Tamarin harbor in the municipality of Solovetsky, where a labor camp was located in 
1919-1939, was erected across from the People's Commissariat for Internal Affairs (NKVD) - later called the Committee for State Security (KGB) headquarters. It thus points out not only the place where the victims had died but also the place where death warrants had been signed. A part of the referent was used pars pro toto as the body of a sign in order to represent the whole. At the same time, it has a strong symbolic character as well. It not only refers to the place where millions of people had suffered but also refers to culturally anchored meanings, such as "gravestone" and "stone as a symbol of remembering the deceased (in Judaism)". As "just a stone", an object created by nature, not humans, it is very effective as a memorial to the victims of the regime, especially in the sense that, as a nonmonumental object of the memorial culture, it displays resistance to the communist regime with its monumental culture, also on the level of a code. ${ }^{8}$

\section{Verbal and Nonverbal Practices}

The memorial was unveiled on October 30, 2017, by the Russian President Vladimir Putin. It was unveiled on the annual Day of Remembrance of the Victims of Political Repressions, which has had the status of a memorial day in Russia since 1991. On this day in 1974, the prisoners in the labor camps went on a hunger strike in protest against the political repressions in the Union of Soviet Socialist Republics and against the inhuman treatment of the prisoners in prisons and labor camps.

In addition to the President, other people also took part in the ceremony: the members of the President's consultative body, viz., The Council for Civil Society and Human Rights; Kirill, the Patriarch of Moscow and the Primate of the Russian Orthodox Church; Sergey Sobyanin, the mayor of Moscow; Naina Yeltsina, the widow of Boris Yeltsin, the first President of Russia; Tatyana Yumasheva, his daughter; Natalia Solzhenitsyn, the widow of writer Solzhenitsyn, and so on.

As far as the ceremony participants are concerned, it may seem rather paradoxical that despite his current institutional identity, the memorial was unveiled by a former KGB lieutenant colonel. It is also paradoxical that the members of the commemorated group, the former political prisoners, protested against the memorial. "The monument is a tribute to the past, and political repressions in Russia not only continue, but their level is increasing", they wrote in their statement (Politzeki 2017).

8 In this regard, compare the concept of "countermonument" in Young (1992, 267-296) and also Krzyżanowska (2016, 465-485).

9 “Pamyatnik - dan' proshlomu, a politicheskie repressii v Rossii ne tol'ko prodolzhayutsya, no i narastayut." 
Let us have a look at how Putin, in his speech at the unveiling of the memorial, constructed the individual participants of the event and its relevance to the present from the linguistic point of view (Prezident 2017).

\section{Perpetrator}

In a part that thematizes the perpetrator, passive constructions are preferred:

“[...] kazhdomu mogli byt' predyavleny nadumannyye $i$ absolyutno absurdnyye obvineniya"; "milliony lyudey obyavlyalis' 'vragami naroda', byli rasstrelyany ili pokalecheny [...]".

"[...] unwarranted and absolutely absurd charges could be brought against anyone"; "millions of people were declared 'enemies of the people', shot or mutilated [...]".

The producer of the statement avoids naming the perpetrator/perpetrators, culprits, or the responsible persons directly. There is an interesting twist in the sole active construction. The active agent is not an institution, a subject, or a collective subject, but an abstract phenomenon - "repressions":

"Repressii ne shchadili ni talant, ni zaslugi pered Rodinoy, ni iskrennyuyu predannost' ey [...]”.

"Repressions did not have mercy upon talent, nor services to the Motherland, nor sincere devotion to it [...]".

Their initiator is thus discursively eliminated; they are constructed as the cause of people's suffering, not as the consequence of some subjects and their actions. Not only what was said, but also what was not said, is important. Vladimir Putin, for instance, did not mention Joseph Stalin, whose name is inseparably linked to the repressions. Moreover, 2017 was a year ending in "7"; 80 years had passed since 1937, the year - which in collective memory is closely connected to the beginnings of repressions.

In comparison, we may, for instance, mention that in 2012, on the annual Day of Remembrance of the Victims of Political Repressions, the former President Dmitry Medvedev (back then, the Prime Minister) concretized "the responsible ones" in his post on Facebook (J. Stalin and those in leading positions) and categorized their actions as "the war against their own nation" and as "the most serious crime". He concretely wrote as follows:

"Iosif Stalin i drugiye rukovoditeli Sovetskogo gosudarstva togo vremeni zasluzhivayut samoy zhestkoy otsenki. Eto dolzhno ostat'sya $v$ annalakh nashey istorii, chtoby nikogda etogo ne povtorilos'. Potomu chto voyna so svoim narodom - eto tyagchaysheye prestupleniye." 
"Joseph Stalin and other leaders of the Soviet Union of that time deserve the toughest assessment. This should remain in the annals of our history, so that it will never happen again. Because the war against own people is the most severe crime."

(Medvedev 2012)

In 2009, on the Day of Remembrance of the Victims of Political Repressions, Medvedev - as the sitting President - coped with the ambivalent memory of Stalin (positively judged victory in World War II, but negatively judged repressions) and discursively solved its axiological incoherence in such a way that Stalin was responsible for all the bad and the Soviet people for all the good things:

“[...] prestupleniya Stalina ne mogut umalit' podvigi naroda, kotoryy oderzhal pobedu v Velikoy Otechestvennoy voyne. Sdelal nashu stranu moguchey industrial'noy derzhavoy. Podnyal na mirovoy uroven' nashu promyshlennost', nauku, kul'turu".

" [...] Stalin's crimes cannot diminish the heroic deeds of the people who won the Great Patriotic War. They made our country a mighty industrial power. They raised our industry, science, culture to the world level."

(Medvedev 2009).

It was a "clever" solution to the dilemma of ensuring that the World War II memory would not be "disgraced" within the memorial culture.

\section{Victims}

The whole nation, society, its roots, culture, and consciousness are constructed as a victim in Putin's speech:

"Politicheskie repressii stali tragediyey dlya vsego nashego naroda, dlya vsego obshchestva, zhestokim udarom po nashemu narodu, ego kornyam, kul'ture, samosoznaniyu."

"Political repression has become a tragedy for all our people, all our society and dealt a harsh blow to our people, its roots, culture and selfconsciousness."

A wide range of victims is delimited according to the social class membership (tselye sosloviya), ethnic group (tselye narody), or profession (rabochie i krest'yane, inzhenery $i$ voenachal'niki, svyashchenniki $i$ gosudarstvennye sluzhashchie, uchenye i deyateli kul'tury/workers, peasants, engineers, military commanders, clergy, government employees, scientists, and cultural figures). 
What is the character of grief?

The repressions are shaped as "the frightening past that cannot be erased from the national memory" (Eto strashnoe proshloe nel'zya vycherknut' iz natsional'noy pamyati $[. .$.$] / This terrifying past cannot be deleted from national$ memory $[. .]$.$) and as the inexcusable action.$

\section{What does it mean for the present?}

Its importance for the present is shaped as the objective "not to forget" and not to let something like this happen again:

“Nash dolg - ne dopustit' zabveniya. Sama pamyat', chetkost' $i$ odnoznachnost' pozitsii, otsenok $v$ otnoshenii etikh mrachnykh sobytiy sluzhat moshchnym predosterezheniyem ot ikh povtoreniya.

"Our duty is to not let it slip into oblivion. Remembrance, a clear and unambiguous position and assessments with regard to those sad events serve as a powerful warning against their recurrence."

The statement discursively favored within the verbal shaping of the 1917 revolution - that the most important things are stability and unity and that it is essential that there is no split and conflict within the society - was present in this speech also:

"Nel'zya snova podtalkivat' obshchestvo k opasnoy cherte protivostoyaniya. Seychas vazhno dlya vsekh nas opirat'sya na tsennosti doveriya i stabil'nosti. Tol'ko na etoy osnove my mozhem reshit'zadachi, kotoryye stoyat pered obshchestvom i stranoy, pered Rossiyey, kotoraya u nas odna."

"We cannot push society to a dangerous line of confrontation yet again. Now, it is important for all of us to build on the values of trust and stability. Only on this basis will we be able to achieve the goals of our society and our country, which is one for us all."

Overall, it may be said that, when constructing the repressions as a persisting trauma of the Russian nation, widening of the chronological framework comes to the fore; not the "Stalinist repressions", but the "political repressions", are taken into account. From the viewpoint of shaping the event, it is a complicated solution, mainly due to its semantic expansiveness. On the one hand, mentioning Stalin in a negative context might have been considered unfavorable by some parts of the population. After the period of Stalin's negative perception (2001-2006), as well as the period of relative inattention, sociologists have recorded, since 2014, an increase in Stalin's positive perception (Levada 2018). On the other hand, narrowing of the time frame (Stalinism) would enable to avoid the generalizations that could mean 
the condemnation of any political repressions, not just the repressions under the USSR.

This storyline has been used in other competing discourses. It is reflected also in the positioning of the holiday. Its original name "The Day of Political Prisoners", being brought to the fore, allows widening of the chronological framework also for the present and for the current political prisoners (Podrabinek 2017). And in this sense, nothing has come to an end; nothing has been concluded so far. State authorities have no moral right to build a memorial, because it may be built only when there is something to commemorate, when something is no longer a current issue, no longer present, visible, audible, and perceivable by our senses, so that we could constantly commemorate "it" despite the immediate, current experience, so that this experience could serve as the axiological landmark for solving the current and future social problems.

As we find from the above-mentioned observations, in the case of the comparative analysis of memorials to the victims of repressions, it would be suitable, from the viewpoint of verbal practices, to pay attention not only to the shaping of the fundamental architecture of the event (name of the event, victim, perpetrator/responsible person, motivation, and character of grief) but also to another aspect that should complete the basis for comparison, namely, the chronological framework and the axis of concretization vs. generalization of the traumatic experience.

\section{Competing Shapings of the Memorial}

As mentioned earlier, in the case of competing articulations, there are basically two types of situations: (a) individual articulations may be bound by various discourse dominants; (b) individual articulations may be defined antagonistically against each other and may be used in a position of the mutually constitutive outside (Laclau 1990, 136-137, 183; Torfing 1999, 124125; compare also Staten 1984, 24). In the case of articulations anchoring the meaning of the memorial by another discourse dominant, its construction as a work of art, as the aesthetic object, comes to the fore. Numerous fragments on "how the memorial was made" or, for instance, interviews with the sculptor Georgy Frangulyan (Medvedev 2018; Odissonova 2017; Kolesnichenko 2017) belong to this category. Another example is the framing - by the Novaya Gazeta newspaper (Martynov 2017) - of the unveiling of the memorial as a part of the preelection campaign of the sitting President Putin. In the case of articulations antagonistically defined against each other, we may name the above-mentioned battle for the signifier/repressions/, which may be shaped as 
something belonging to the field of Stalinism, the communist regime, or the state power in Russia in general.

\section{Conclusion}

In this text, we have elaborated the methodological procedures for a comparative research into the artifacts of memorial culture. As far as the communication framework is concerned, we came to the conclusion that it is necessary to differentiate on the "formality"/ "institutionality"/"from above""spontaneity" axis. In the context of the analyzed memorial, it was articulated as "from above". On the "formality"/ institutionality"-"spontaneity" axis, the articulations formulated by the Russian leaders may be assessed as official and in contrast to practices such as, for instance, the reading of names at the Solovetsky Stone memorial (which has been held annually since 2007).

When speaking of verbal practices, the following should primarily come to the fore in the course of the analysis: (a) the questions on shaping the victim and the perpetrator; (b) widening vs. narrowing of the chronological framework; generalization vs. concretization; and specification of the traumatic experience ("Stalinist repressions" vs. "political repressions" in general); and (c) the question of framing the memorial (as aesthetic object, object of the memorial culture, place of pilgrimage, and sacral object).

Considering the object of the memorial as a message, it is relevant to focus on the questions of the hierarchy of functions (here, we have taken into consideration mainly the cognitive, emotive, and axiological functions) in the case of its most probable reading.

On the syntagmatic axis, we consider it helpful to single out, during the process of analysis, the key elements of the memorial and to focus on their categorization, e.g., on the concreteness vs. abstractness axis or figures vs. objects axis, and on the visual creation of the relationships between them. As to the paradigmatic axis, thinking about the missing elements comes to the fore. In this context, it is appropriate to have the knowledge of other artifacts that form one paradigm with the analyzed "text".

In the context of the used signs, we consider it especially important to identify their relationship to the entity they represent and to differentiate whether they are the icons (resemblance), indices (causal relationship), or symbols (arbitrariness), as well as to think about the metamorphoses of individual signs, such as the symbolization of icons and indices, which enables transparent and effective communication. In the case of the memorial culture, the extent of indexicality is considered to be very important in the sense of the bodily 
connection with an element of the commemorated event, which bestows "truthfulness" and authenticity on the memorial.

The presented model of analysis brings about possibilities of a deeper interpretation of events in memory politics in Russia. The perception of the memorial as a crossroad of verbal and nonverbal practices makes it possible to understand the mechanisms of anchoring of meanings. A diversified approach to research on language-mediated and nonlinguistic practices makes it possible to take into account the specificities of the codes used to communicate content and provides a basis for broader comparative research. At the same time, it makes it possible to point out how articulations can work together to produce particular episteme and observe situations when the official narrative abstracted from individual utterances of government officials is "detached" from other nonverbal practices. It is this constellation that opens up, in our view, possibilities for other competitive narratives, which - through articulations - will be more authentic in interpreting events.

\section{Acknowledgements}

This paper is an output of the project KEGA Course Book on Political Linguistics (grant 015EU-4/2019).

\section{References}

\section{Secondary Sources}

Assmann, Aleida. 2013. Das neue Unbehagen an der Erinnerungskultur: Eine Intervention. München: C.H. Beck, 2013.

Assmann, Jan. 1988. Kollektives Gedächtnis und kulturelle Indentität. In: Assmann, J. Hölscher, T. (Hrsg.): Kultur und Gedächtniss. Frankfurt am Main: Suhrkamp, 1988, s. 9-20.

Barthes, Roland. 1977. Rhetoric of the Image. In Image. Music. Text. Essays selected and translated by Stephen Heath, 32-52. London: Fontana Press.

Bogumił, Zuzanna. 2012. Pamięć Gutagu. Kraków: Universitas.

Eco, Umberto. 1976. A Theory of Semiotics. Bloomington, London: Indiana University Press.

Etkind, Alexander. 2013. Warped Mourning. Stories of the Undead in the Land of the Unburied. Stanford: Stanford University Press.

Fillmore, Charles J. 1982. Frame Semantics. In Linguistics in the Morning Calm. Selected Papers from SICOL-1981, edited by The Linguistic Society of Korea,. Soul: Hanshin Publishing Company, 111-137.

Foucault, Michel. 2002. The Archaeology of Knowledge. Translated by A. M. Sheridan Smith. London, New York: Routledge.

Hjelmslev, Louis. 1969. Prologomena to a Theory of Language. Translated by Francis J. Whitfield. Madison, Milwaukee, London: The University of Wisconsin Press. 


\section{Nina Cingerová, Irina Dulebová \\ Rock Beats the Wall? On Commemorative Practices in Post-Soviet Russia}

Chandler, Daniel. 2007. Semiotics. The Basics. London, New York: Routledge.

Jäger, Margarete and Jäger, Siegfried. 2007. Deutungskämpfe. Theorie und Praxis Kritischer Diskursanalyse. Wiesbaden: VS Verlag für Sozialwissenschaften.

Jørgensen, Marianne and Phillips, Louise. 2002. Discourse Analysis as Theory and Method. London, Thousand Oaks, New Delhi: Sage Publications.

Kalinin, Il'ya. 2017. Prizrak yubileya. Neprikosnovennyy zapas 2017/1. http://magazines.russ. $\mathrm{ru} / \mathrm{nz} / 2017 / 1 /$ prizrak-yubileya.html. Accessed 10.05.2019.

Keller, Rudi. 1995. Zeichentheorie: Zu einer Theorie Semiotischen Wissens. Tübingen, Basel: Francke, 1995.

Koposov, Nikolay. 2011. Pamyat'strogogo rezhima. Istoriya i politika v Rossii. Moskva: Novoye literaturnoye obozreniye.

Kress, Gunther. 2010. Multimodality: A Social Semiotic Approach to Contemporary Communication. London, New York: Routledge.

Krzyżanowska, Natalia. The Discourse of Counter-Monuments: Semiotics of Material Commemoration in Contemporary Urban Spaces. Social Semiotics, 26:5, 2016, 465-485.

Laclau, Ernesto and Mouffe, Chantal. 2001. Hegemony and Socialist Strategy. Towards a Radical Democratic Politics. Second Edition. London, New York: Verso.

Laclau, Ernesto. 1990. New Reflections on the Revolution of Our Time. London, New York: Verso.

Osolsobě, Ivo. 2002. Ostenze, hra, jazyk. Sémiotické studie. Brno: Host.

Peirce, Charles Sanders. 1972. Charles Sanders. Lingvistické čítanky 1., Sémiotika sv. 1. Praha: SPN, 1972.

Reisigl, Martin and Wodak, Ruth. 2001. Discourse and discrimination: Rhetorics of racism and antisemitism. London; New York: Routledge.

Rostovtzev, Evgeny, A. - Sosnytskiy, Dmitry A. Napravlenyya issledovaniy istoricheskoy pamyati v Rossii. In Vestnik Sankt-Peterburgskogo universiteta, Ser. 2, Vyp. 2, 2014, p. 106 $-126$.

Searle, John Rogers. 1995. Social Construction of Reality. New York: The Free Press.

Staten, Henry. 1984. Wittgenstein and Derrida. Lincoln, London: University of Nebraska Press.

Torfing, Jacob. 1999. New Theories of Discourse: Laclau, Mouffe and Žižek. Oxford, Malden: Blackwell Publishers.

Yakobson, Roman. 1975. Lingvistika i poetika. Perevod s angliyskogo I. A. Mel'chuka. In Strukturalizm: "za" $i$ "protiv", edited by Yevgeniy Basin and Mark Polyakov, 193-231. Moskva: Izdatel'stvo "Progress".

Young, James E. 1992. The Counter-Monument: Memory against Itself in Germany Today. In Critical Inquiry, Vol. 18, No. 2. (Winter, 1992), 267-296.

\section{Primary Sources}

“Adres". Fond Posledniy adres. https://www.poslednyadres.ru/. Accessed 10.05.2019. 


\section{Journal of Nationalism, Memory \& Language Politics 14(1)}

Bevza, Dmitriy. 2018. Narisovat' delo: kak v Rossii sazhayut za reposty. Gazeta.ru, 2018, August 19. https://www.gazeta.ru/tech/2018/08/18/11899507/two_years.shtml?updated. Accessed 10.05.2019.

"Bortnikov". Bortnikov, Alexandr and Fronin, Vladislav. FSB rasstavlyaet aktsenty. 2017, Rossiyskaya gazeta. 2017. December 19. https://rg.ru/2017/12/19/aleksandr-bortnikov-fsbrossii-svobodna-ot-politicheskogo-vliianiia.html. Accessed 10.05.2019.

Giniatulina, Leyla. 2010. Tak vozvrashchayutsya imena. Radio Svoboda. 2010, October 29. https://www.svoboda.org/a/2204499.html. Accessed 10.05.2019.

Kolesnichenko, Alexandr. 2017. "Stena Skorbi": kak sozdayut pamyatnik zhertvam politicheskikh repressiy. Argumenty i fakty, 2017, May 31. http://www.aif.ru/society/gallery/stena_skorbi_kak_sozdayut_pamyatnik_zhertvam_politicheskih_repressiy. Accessed 10.05.2019.

"Levada 2017". Vydayushchiyesya lyudi. Press Vypusk. 2017, June 26. https://www.levada. ru/2017/06/26/vydayushhiesya-lyudi/. Accessed 10.05.2019.

“Levada 2018”. Rossiyane stali ravnodushnee k Stalinu. 2018, April 10. https://www.levada. $\mathrm{ru} / 2018 / 04 / 10 /$ rossiyane-stali-ravnodushnee-k-stalinu/. Accessed 10.05.2019.

“Medvedev 2012". Facebook. 2012, October 30. https://www.facebook.com/Dmitry.Medvedev/posts/10151092413876851. Accessed 10.05.2019.

“Medvedev 2009”. Pamyat' o natsional'nykh tragediyakh tak zhe svyashchenna, kak pamyat' o pobedakh. 2009, October 30. http://www.kremlin.ru/events/president/news/5862. Accessed 10.05.2019.

Medvedev, Sergey. 2018. Po kom plachet "tena skorbi"? Kak sozdavalsya memorial zhertvam repressiy na prospekte Sakharova. Dozhd', 2018, April 12. https://tvrain.ru/teleshow/medvedev/po_kom_plachet_stena_skorbi-461700/. Accessed 10.05.2019.

Odissonova, Viktoriya. 2017. “Stena skorbi”. Kak sozdayut pervyy v Rossii monument zhertvam massovykh repressiy. Novaya gazeta, 2017, May 31. https:/www.novayagazeta.ru/ articles/2017/05/31/72649-stena-skorbi. Accessed 10.05.2019.

"Pamyatniki". Pamyatniki zhertvam politicheskikh repressiy na territorii byvshego SSSR. https://www.sakharov-center.ru/asfcd/pam/. Accessed 10.05.2019.

Podrabinek, Alexandr. 2017. O chem molchit "Stena skorbi”. Grani.ru, 2017, October 28. https://echo.msk.ru/blog/podrabinek/2081914-echo/. Accessed 10.05.2019.

"Politzeki". Byvshie sovetskiye politzeki: Otkrytiye "Steny skorbi" - litsemeriye. Grani.ru, 2017, October 30. https:/graniru.org/Politics/Russia/Politzeki/m.265179.html\#full. Accessed 10.05.2019.

"Prezident". Otkrytiye memoriala pamyati zhertv politicheskikh repressiy "Stena skorbi”. 2017, October 30. http://www.kremlin.ru/events/president/news/55948. Accessed 10.05.2019.

Racheva, Yelena. 2016. Kleymo poryadochnogo cheloveka. Novaya gazeta. 2016, October 7. https://www.novayagazeta.ru/articles/2016/10/07/70094-kleymo-poryadochnogo-cheloveka. Accessed 10.05.2019.

"Sova”. Rafisa Kashapova priznali vinovnym v prizyvah k separatizmu i vozbuzhdenii nenavisti. 2015, September 15. https://www.sova-center.ru/misuse/news/persecution/2015/09/ d32800/. Accessed 10.05.2019. 
Nina Cingerová, Irina Dulebová Rock Beats the Wall? On Commemorative Practices in Post-Soviet Russia

"Zhertvy". Obshchiye bazy zhertv repressiy. Memorial. https://www.memo.ru/ru-ru/historyof-repressions-and-protest/victims/obshie-bazy-zhertv-repressij/. Accessed 10.05.2019.

Yemelyanenko, Vladimir. 2017. Yabloni v svechakh. Rossiyskaya gazeta. 2017, September 27. https://rg.ru/2017/09/27/reg-cfo/v-moskve-na-meste-kazni-zhertv-repressij-1937-g-otkrylisad-pamiati.html. Accessed 10.05.2019. 